\title{
THE RANKING OF FIRMS FROM ROMANIA, ALBA COUNTY BASED ON THEIRS TURNOVER, NET PROFIT AND TOTAL DEBTS
}

\author{
Sorin-Constantin Deaconu ${ }^{1}$
}

\begin{abstract}
This paper investigates the accuracy of Top of the Companies elaborated by Alba County Chamber of Commerce and Industry and Agriculture based on theirs turnover. Thus, we want a correction to be made for the Top of the Companies and a change to be made for the Chamber of Commerce and Industry of Romania Regulation in what concerns the way to establish the order in which companies are ranked in the county competition. The analysis was performed by calculating the coefficient of variation. The results show that the Top of the Companies was not properly determined so we have proposed elaboration of another ranking based on company's turnover, net profit and total debts. The result of the latter ranking showed a strong dependency between the two indicators by calculating Pearson's coefficient.
\end{abstract}

Key words: turnover, coefficient of variation, profit and loss account, Pearson's coefficient, financial statements.

JEL codes: $M 41$, A 12

Introduction

This paper intends to research the Top of the Companies elaborated by the Chamber of Commerce and Industry of Romania, respectively the ranking of the companies listed in the Top in question. This Top will be analyzed in terms of indicators taken into account for preparing it. We want to find out if the Top in question was properly or not properly elaborated by the Chamber of Commerce and Industry of Romania.

In order to analyse the Top of the Companies there were used various research methods such as: statistical methods, namely Pearson's coefficient that's establishes a relationship between turnover and total debt; graphical representation through which was visually drawn up the value of turnover obtained by the companies listed in the Top elaborated by the Chamber of Commerce and Industry of Romania.

After performing our research we consider that the Top of the Companies elaborated by the Chamber of Commerce and Industry of Romania is unrealistic and unfair, so we have proposed elaboration of another ranking based on company's turnover, net profit and total debts.

\section{Literature review}

The documentation work was performed by:

$>$ Revising of the specialty literature. Any research work is based on what was studied and was published until a certain moment of time in a field. For example at international level Chin-Chun Hsu and David J. Boggs conducted a study on a large sample of entities taking into account the profit margin, the external sales etc. in order to measure the effects on financial performance of companies.

$>$ Studying the normative and other documents. This method involves analyzing the documents in question using some parameters set out in relation to the scope and the objectives of the research. For the present paper were studied documents such as:

\footnotetext{
${ }^{1}$ University „1 Decembrie 1918” Alba Iulia, Alba Iulia, e-mail: deaconu_sorin@uab.ro.
} 
Order no. 3055/2009 concerning the approval of the accounting regulations according with the European Directive, The accounting law no. 82/1991, republished, with further amendments and completions, Order of the President of National Institute of Statistics regarding the updating of national economy classification of activities - NACE no. 337/2007 and others.

$>$ Qualitative approach involves entering into the intimacy of real or imaginary structures through interpretation, naturalistic explanation, understanding, comprehension. Thus the generalization is possible by moving from individual to general using the induction process.

$>$ Indicator is a constructed size, determined or operational derived from primary data expressing the volume, value or structure of a corporate or a feature in absolute values. Concretely, in the present paper, we will use Pearson's contingency coefficient in order to express and measure the links between turnover and total debt.

\section{Assumptions}

Assumption 1: the Top of the Companies among firms is correctly elaborated by Alba Chamber of Commerce and Industry based on turnover. This hypothesis will be tested by determining the variation coefficient for the 10 firms classified.

Assumption 2: reclassification of companies based on turnover, net profit and total debt by extending the sample. This hypothesis is tested by determining the correlation coefficient.

\section{Consideration about the turnover}

The financial statements are flooded by numbers and provide information for different types of users. In Romania, the large entities elaborate a set of financial statements, consisting in: balance sheet, income statement, statement of changes in equity, cash flow statement, notes to the annual financial statements. All five documents should be considered equally important. Among the components listed only profit and loss account and notes to financial statements provide information about annual turnover. To determine the turnover data are taken (income) in the trial balance. In Romania the large entities elaborates a set of financial statements formed by: balance sheet, profit and loss statement, statement of changes in equity, statement of cash flows, notes to the financial statements. All those five documents should be considered as equally important. Only the profit and loss statement and the notes to the financial statements offer information about the turnover. In order to calculate the turnover there are data (revenues) to be processed from the balance trial.

Turnover represents and indicator useful for:

$>$ public procurement procedures. For example, a company that wants to participate in the award of a public procurement contract must present documents revealing "overall turnover / turnover in the field in question for the procurement for a period previous to the award covering more than last three years "(the Order of the National Authority for Regulating and Monitoring Public Procurement regarding the qualification and selection drawing up no. 509/2011, Official Journal no. 687/2011).

$>$ the elaboration of the cause and circumstances reports elaborated by the liquidator for a company in insolvency ${ }^{(1)}$.

$>$ in various internal analyzes of the corporations regarding their activities aiming at a series of correlations between the dynamics of turnover, production of the financial year, the added value, etc;

$>$ the elaboration of national statistics by the National Institute of Statistics;

$>$ Considering the above mentioned arguments we are entitled to proceed in our approach to the study of turnover. 
Revenue is defined in the General framework as increases in economic benefits during the accounting period in the form of inflows or enhancements of assets or decreases of liabilities that result in increases in equity, other than those relating to contributions from equity participants.

Revenue is recognised in the profit and loss statement as part of the financial statements when it meets the following criteria:

$>$ it is probable that any future economic benefit associated with the item of revenue will flow to the entity

$>$ the amount of revenue can be measured with reliability

In Romania the expenses and revenues are classified by their nature as:

$>$ operating expenses ad revenues;

$>$ financial expenses ad revenues;

$>$ extraordinary expenses ad revenues.

This is a unique classification in economy being used by the all companies.

The performance of an entity depends on its costs, revenues and results. This can be calculated using the next formula:

$$
1 \pm \text { Result }=\text { Revenues }- \text { Expenses } \quad 1
$$

The result may be positive, namely profit (revenues exceed expenses) or negative, namely loss (revenues are lower than expenses). We can say that there is difference between the „expense” - „loss" and „revenue” - ,profit” concept pairs.

Frequently, the profit is confused with the treasury of an entity. This confusion is the result of wrong perception of the revenue and expenses concept. There is a habit to consider any payment as an expense and any cash collecting as revenue. Should be take into account the period of time between sales, purchases and receipts, respectively payments. Thus, revenue is recognized, usually when hiring a claim and expense, when hiring a debt (accrual). There may be situations where an entity records profit (for which owes income tax to the state budget), but only a small part of the profit can be found in company's Treasury (Feleagă, Malciu, Bunea, 2002). Thus, revenue is recognised when it is earned and the expense when it incurred rather than when payment is made or received (accrual basis accounting).

Turnover is an indicator with multiple meanings, both theoretical and especially practical.

Theoretically, we present several definitions of turnover:

Romanian law maker defines the net turnover as the amounts obtained from the sale of products and services provided in company's current activity after deducting trade discounts and value added tax and other fees directly related to turnover (Order 3055/2009 for approval of accounting regulations in accordance with European Directives, Official Journal no. 766 bis/2009). The Romanian law maker defines net turnover as the amounts of annual sales of goods and services resulting from a firm current activity reduced by discounts, value added tax and other taxes directly linked to it (Order no. 3055/2009 for the approval of accounting regulations in accordance to the European Directives, Official Journal no. 766 bis/2009).

Generally, the economic literature define turnover as cash collected company's self activity.

In our opinion, the turnover is an indicator that expresses the actual revenues recorded in strict relation to the entity's activity during a period of time, but not the value of cash collected.

The indicator called net turnover is calculated in the profit and loss statement: 


\section{Extract form the Profit and Loss Statement in Romania}

Table no. 1 . at 31.12. ${ }^{(2)}$ in accordance with MPFO no. 3055/2009 (lei)

\begin{tabular}{|l|r|r|r|}
\hline \multirow{2}{*}{ INDICATOR NAME } & Nr & \multicolumn{2}{c|}{ Financial year } \\
\cline { 4 - 4 } & rd. & Prior & \multicolumn{1}{c|}{ Current } \\
\hline 1. NET TURNOVER (rd. 02 la 06) & 01 & 6.214 .820 & 8.622 .304 \\
\hline Sales of finished goods & 02 & 5.401 .537 & 7.381 .962 \\
\hline Sale of goods purchased for resale & 03 & 308.958 & 600.861 \\
\hline Trade discounts granted & 04 & & \\
\hline $\begin{array}{l}\text { Interest income recorded by the entities removed from the } \\
\text { General Ledger and have ongoing leasing contracts }\end{array}$ & 05 & & \\
\hline Income from subsidies related to net turnover & 06 & 504.325 & 639.481 \\
\hline 2. Income related to the cost of production in progress & & & \\
\hline \multicolumn{1}{|c|}{ Credit balance } & 07 & 1.586 .235 & 2.758 .962 \\
\hline \multicolumn{1}{|c|}{ Balance due } & 08 & & \\
\hline $\begin{array}{l}\text { 3. Production obtained by the entity for its own purposes } \\
\text { and capitalized }\end{array}$ & 09 & & \\
\hline 4. Other operating revenues & 10 & 98.825 & 100.318 \\
\hline$\quad$ - of which, income from negative goodwill & 11 & & \\
\hline Operating revenues - total (rd. 01+07-08+09+10) & 12 & 7.899 .880 & 11.481 .584 \\
\hline
\end{tabular}

Analyzing the above table we may conclude that:

$>$ the Romanian profit and loss statement is elaborated based on a standard template which is the same for the national economy;

$>$ the turnover it's formed in its majority by operating revenues and does not include the revenues corresponding to the cost of unfinished goods, own work capitalised and other operating revenues;

$>$ the indicator "production of the accounting year" does not appear explicitly in the template provided by the Ministry of Public Finance Order no. 3055/2009. This may be cited as a drawback for the calculation of intermediate management balances and for entity-level analysis.

In order to perform a comparative analyse we present bellow an extract of Canadian Profit and Loss Statement:

Table no.2.

Extract form the Profit and Loss Statement in Canada at $30^{\text {th }}$ September $\mathrm{N}^{(3)}$ (Canadian dollar)

\begin{tabular}{|l|r|r|r|r|}
\hline \multicolumn{1}{|c|}{ INDICATOR NAME } & \multicolumn{1}{c|}{$\begin{array}{c}\text { September N } \\
\text { ACTUAL }\end{array}$} & $\begin{array}{c}\text { September N-1 } \\
\text { PRIOR YEAR }\end{array}$ & $\begin{array}{c}\text { YTD N } \\
\text { ACTUAL }\end{array}{ }^{(4)}$ & $\begin{array}{c}\text { YTD N-1 } \\
\text { PRIOR } \\
\text { YEAR }\end{array}$ \\
\hline SALES & 24.679 .654 & 27.906 .920 & 310.220 .292 & 305.198 .667 \\
\hline REVENUE WARRANTIES & 1.549 .462 & 1.888 .057 & 19.941 .394 & 20.278 .832 \\
\hline $\begin{array}{l}\text { REVENUE - CAR INSTALL } \\
\text { LABOR }\end{array}$ & 601.974 & 624.209 & 6.609 .746 & 6.362 .679 \\
\hline REVENUE - CAR PARTS & 252.562 & 257.992 & 2.860 .418 & 2.664 .086 \\
\hline REVENUE - HOME INSTALL & 398.309 & 340.638 & 4.194 .376 & 3.634 .789 \\
\hline SALES ADJUSTMENTS & 30.436 & 35.792 & 161.846 & 275.504 \\
\hline TOTAL SALES & $\mathbf{2 7 . 5 1 2 . 3 9 7}$ & $\mathbf{3 1 . 0 5 3 . 6 0 9}$ & $\mathbf{3 4 3 . 9 8 8 . 0 7 1}$ & $\mathbf{3 3 8 . 4 1 4 . 5 5 6}$ \\
\hline
\end{tabular}

The extract of Canadian profit and loss statement shows that: 
the Canadian profit and loss statement is elaborated for the period between $1^{\text {st }}$ October $-30^{\text {th }}$ November, thus revealing more completely the activity of a certain entity;

$>$ the total sales have an increasing trend in the current financial year compared to the previous one. The increase is $101.64 \%$ which allows the entity to continue the current practice of economic policy this may be even improved;

After a brief presentation of some aspects related to the turnover next we will analyse the Top of the Companies elaborated by Alba County Chamber of Commerce, Industry and Agriculture.

The Top of the Companies elaborated by Alba County Chamber of Commerce and Industry and Agriculture - resultants and debates

It is mandatory, in accordance to Law no. 335/2007 (article 4, "m" letter) of Chamber of Commerce and Industry of Romania, published in Official Journal no. 836/2007, for the Alba County Chamber of Commerce, Industry and Agriculture to annually organise a Top of the Companies and to recompense firms' efforts.

We present bellow the Top of Companies elaborated by Alba County Chamber of Commerce, Industry and Agriculture, based on turnover for the year 2009.

Table no. 3 .

Top of the Companies elaborated by Alba County Chamber of Commerce and Industry and Agriculture for 2009 (lei)

\begin{tabular}{|c|l|l|c|}
\hline Position & \multicolumn{1}{|c|}{ Company name } & \multicolumn{1}{c|}{ Activity } & Score $^{(5)}$ \\
\hline 1. & $\begin{array}{l}\text { SC HOLZINDUSTRIE } \\
\text { SCHWEIGHOFER SRL }\end{array}$ & Sawmilling and planning of wood & 100 \\
\hline 2. & SC KRONOSPAN SEBEŞ SA & - Manufacture of wood products & 62,60 \\
\hline 3. & SC ELIT SRL & $\begin{array}{l}\text { Production, processing and } \\
\text { preserving of meat }\end{array}$ & 34,80 \\
\hline 4. & SC TRANSAVIA SA & Poultry & 34,70 \\
\hline 5. & SC ALBALACT SA & Dairies & 25,80 \\
\hline 6. & SC MERCADO SRL & $\begin{array}{l}\text { Production, processing and } \\
\text { preserving of meat }\end{array}$ & 17,40 \\
\hline 7. & SC PEHART TEC SA & Paper and cardboard & 14,70 \\
\hline 8. & $\begin{array}{l}\text { SC JIDVEI SRL FILIALA } \\
\text { ALBA }\end{array}$ & Beverage crop & 0,10 \\
\hline 9. & SC REKORD SRL & Manufacture of footwear & 0,09 \\
\hline 10. & SC BOSCH REXROTH SRL & $\begin{array}{l}\text { Manufacture of bearings, gears, } \\
\text { gearboxes and mechanical } \\
\text { transmission elements }\end{array}$ & 0,09 \\
\hline
\end{tabular}

Source: http://www.cciaalba.ro/top_ca.html, 3 December 2011

Bellow we present the figures of turnover for each of the companies included in the above table. 


\section{Table no. 4.}

Turnover recorded by the firms listed in the Top of the Companies elaborated by Alba County Chamber of Commerce and Industry and Agriculture for 2009 (lei)

\begin{tabular}{|c|l|r|}
\hline Position & \multicolumn{1}{|c|}{ Company name } & \multicolumn{1}{c|}{ Turnover } \\
\hline 1. & SC HOLZINDUSTRIE SCHWEIGHOFER SRL & $875.673 .942,00$ \\
\hline 2. & SC KRONOSPAN SEBEŞ SA & $547.973 .772,00$ \\
\hline 3. & SC ELIT SRL & $304.892 .075,00$ \\
\hline 4. & SC TRANSAVIA SA & $304.178 .862,00$ \\
\hline 5. & SC ALBALACT SA & $225.975 .200,00$ \\
\hline 6. & SC MERCADO SRL & $152.485 .115,00$ \\
\hline 7. & SC PEHART TEC SA & $129.134 .483,00$ \\
\hline 8. & SC JIDVEI SRL FILIALA ALBA & $89.198 .043,00$ \\
\hline 9. & SC REKORD SRL & $85.006 .137,00$ \\
\hline 10. & SC BOSCH REXROTH SRL & $81.918 .700,00$ \\
\hline
\end{tabular}

Source: http://www.mfinante.ro/agentinume.html?pagina=domenii,

\section{December 2011}

Alba County Chamber of Commerce, Industry and Agriculture has elaborated the ranking taking into account only one indicator, namely turnover and did not correlate it with entity's object of activity. It was used as standard the turnover of SC HOLZINDUSTRIE SCHWEIGHOFER SRL in amount of 875.673.942,00 lei. According to this value there were scored the other companies listed in the top.

The present study was made of the following rational reasons: to correctly inform the audience about the entities that have a consolidated position on the county and national market, to make the promotion of entities that have worked hard to run profitable businesses and had a substantial contribution to the budget's revenues.

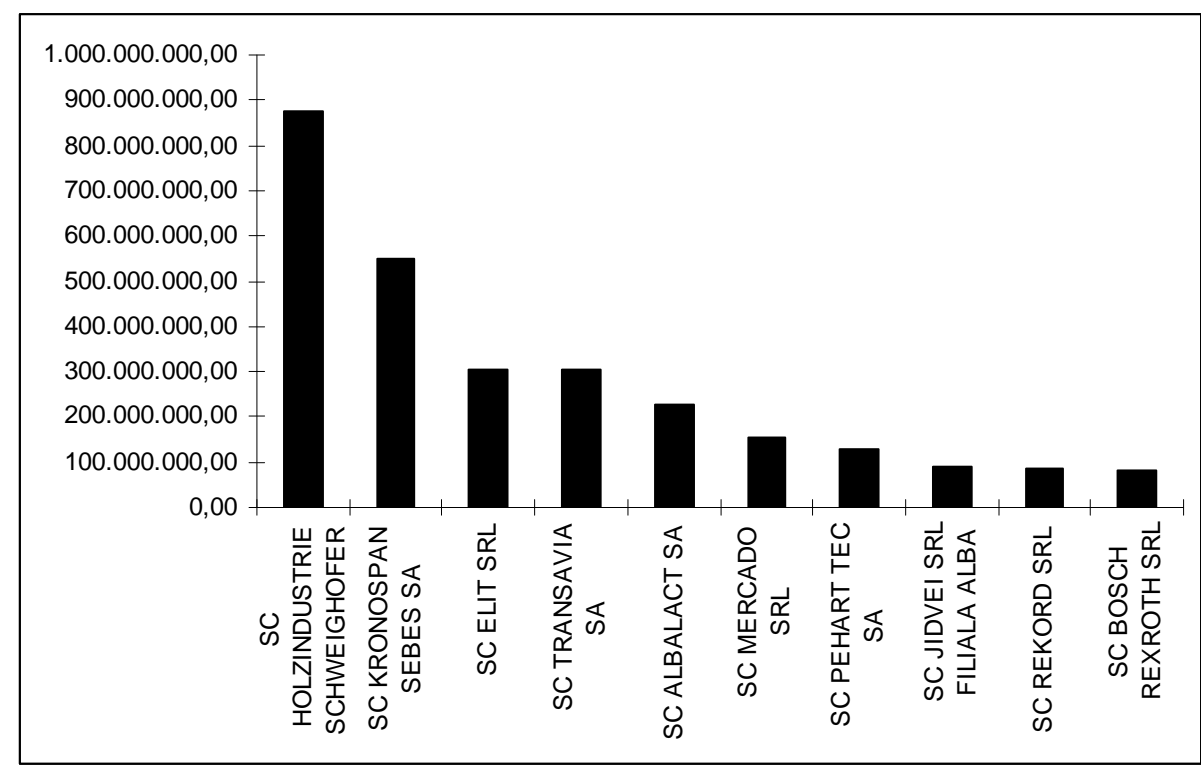

Figure no.1. - Graphical representation of the turnover for the firms listed in the Top of the Companies elaborated by Alba County Chamber of Commerce and Industry and Agriculture for 2009 (lei)

In terms of turnover, we believe that the Top of the Companies elaborated and presented in the above graphic reflects reality, but only in terms of sales revenue. If it were taken into account 
other variables the Top may have been different. Consequently, we present bellow other indicators together with turnover in order to judge things corollary:

Table no. 5 .

Turnover, gross profit, net profit and total debts recorded by the entities listed in the Top of the Companies elaborated by Alba County Chamber of Commerce and Industry and Agriculture in 2009 (lei)

\begin{tabular}{|l|r|r|r|r|}
\hline \multicolumn{1}{|c|}{ Company name } & \multicolumn{1}{c|}{ Turnover } & \multicolumn{1}{c|}{ Gross profit } & \multicolumn{1}{c|}{ Net profit } & \multicolumn{1}{c|}{ Total debt } \\
\hline $\begin{array}{l}\text { SC HOLZINDUSTRIE } \\
\text { SCHWEIGHOFER SRL }\end{array}$ & $875.673 .942,00$ & $101.229 .949,00$ & $101.201 .282,00$ & $647.280 .701,00$ \\
\hline SC KRONOSPAN SEBES SA & $547.973 .772,00$ & $-90.351 .818,00$ & $-90.380 .485,00$ & $564.957 .727,00$ \\
\hline SC ELIT SRL & $304.892 .075,00$ & $39.098 .639,00$ & $35.582 .812,00$ & $84.650 .325,00$ \\
\hline SC TRANSAVIA SA & $304.178 .862,00$ & $17.234 .825,00$ & $14.363 .817,00$ & $108.665 .931,00$ \\
\hline SC ALBALACT SA & $225.975 .200,00$ & $2.805 .932,00$ & $2.603 .779,00$ & $95.603 .352,00$ \\
\hline SC MERCADO SRL & $152.485 .115,00$ & $4.690 .883,00$ & $3.731 .791,00$ & $31.561 .012,00$ \\
\hline SC PEHART TEC SA & $129.134 .483,00$ & $459.012,00$ & $148.437,00$ & $176.213 .919,00$ \\
\hline $\begin{array}{l}\text { SC JIDVEI SRL FILIALA } \\
\text { ALBA }\end{array}$ & $89.198 .043,00$ & $4.870 .825,00$ & $3.470 .974,00$ & $48.771 .790,00$ \\
\hline SC REKORD SRL & $85.006 .137,00$ & $9.864 .535,00$ & $8.335 .294,00$ & $29.851 .498,00$ \\
\hline SC BOSCH REXROTH SRL & $81.918 .700,00$ & $-1.521 .425,00$ & $-1.550 .092,00$ & $167.176 .524,00$ \\
\hline
\end{tabular}

Source: http://www.mfinante.ro/agentinume.html?pagina=domenii, 3 December 2011

We consider useful to promote the entities carrying on overall an activity that generates cash flows resulting in budgetary revenues through taxes and fees paid. Thus, in order to achieve an accurate, fair and true ranking we will perform calculations using turnover with other indicators, namely: gross profit, net profit and total debt.

To make a deeper analysis of the accuracy of the Top of the Companies presented in Table 3 we calculate the correlation coefficient. For this we make the following notations:

$$
\begin{aligned}
& \mathrm{x}_{\mathrm{i}}-\text { turnover } \\
& \bar{x} \text { - average turnover } \\
& \mathrm{n}-10 \\
& \sigma_{\mathrm{x}}^{2}-\text { dispersion } \\
& \sigma_{\mathrm{x}}-\text { standard deviation } \\
& \mathrm{v}_{\mathrm{x}}-\text { coefficient of variation }
\end{aligned}
$$

\section{Finding the coefficient of variation}

Stage 1: Calculating the average turnover:

$$
\bar{x}=\frac{\sum_{i=1}^{n} x_{i}}{n}=\frac{875.673 .942+547.973 .772+\ldots+81.918 .700}{10}=279.643 .632,90
$$

Stage 2: Calculating the dispersion (to be use the below table): 
Dispersion calculation

\begin{tabular}{|c|c|c|c|}
\hline Company name & $\mathrm{x}$ & $\mathrm{x}-\bar{x}$ & $(x-\bar{x})^{2}$ \\
\hline $\begin{array}{l}\text { SC HOLZINDUSTRIE } \\
\text { SCHWEIGHOFER SRL }\end{array}$ & $875.673 .942,00$ & $596.030 .309,10$ & $355.252 .129 .365 .842 .000,00$ \\
\hline SC KRONOSPAN SEBES SA & $547.973 .772,00$ & $268.330 .139,10$ & $72.001 .063 .549 .425 .400,00$ \\
\hline SC ELIT SRL & $304.892 .075,00$ & $25.248 .442,10$ & $637.483 .828 .477 .054,00$ \\
\hline SC TRANSAVIA SA & $304.178 .862,00$ & $24.535 .229,10$ & 601.977.466.989.488,00 \\
\hline SC ALBALACT SA & $225.975 .200,00$ & $-53.668 .432,90$ & $2.880 .300 .689 .941 .800,00$ \\
\hline SC MERCADO SRL & $152.485 .115,00$ & $-127.158 .517,90$ & $16.169 .288 .674 .524 .600,00$ \\
\hline SC PEHART TEC SA & $129.134 .483,00$ & $-150.509 .149,90$ & $22.653 .004 .203 .620 .700,00$ \\
\hline $\begin{array}{l}\text { SC JIDVEI SRL FILIALA } \\
\text { ALBA }\end{array}$ & $89.198 .043,00$ & $-190.445 .589,90$ & $36.269 .522 .712 .359 .000,00$ \\
\hline SC REKORD SRL & $85.006 .137,00$ & $-194.637 .495,90$ & $37.883 .754 .810 .222 .500,00$ \\
\hline \multirow[t]{3}{*}{ SC BOSCH REXROTH SRL } & $81.918 .700,00$ & $-197.724 .932,90$ & $39.095 .149 .090 .309 .500,00$ \\
\hline & & $\sum_{i=1}^{10}\left(x_{i}-\bar{x}\right)^{2}$ & $583.443 .674 .391 .712 .000,00$ \\
\hline & & $=\frac{\sum_{i=1}^{10}\left(x_{i}-\bar{x}\right)}{10-1}$ & $64.827 .074 .932 .412 .400,00$ \\
\hline
\end{tabular}

Stage 3: Standard deviation:

$$
\sigma_{x}=\sqrt{\sigma_{x}^{2}}=\sqrt{64.827 .074 .932 .412 .400}=254.611 .615,86 \quad 3
$$

Stage 4: Coefficient of variation:

$$
v_{x}=\frac{\sigma_{x}}{\bar{x}}=\frac{254.611 .615,86}{279.643 .632,90} \times 100=91,04 \% \quad 4
$$

The coefficient of variation is $91,04 \%$. Since the coefficient of variation is very high, the hypothesis is not proven, because the average is not representative and "population" is not homogeneous. Specifically, the top elaborated by Alba County Chamber of Commerce, Industry and Agriculture for 2009 does not reflect reality, because it was considered only a single tie criterion, namely turnover. Another argument that proves that the top is not properly elaborated is the fact that two entities recorded losses during the financial year 2009 (SC KRONOSPAN SEBEŞ SA, which recorded a net loss of - 90.380.485,00 lei and Bosch Rexroth Ltd, which recorded a net loss of - 1,550,092.00 lei).

From our point of view the comparison is not eloquent, primarily because the entities having different object of activity are not comparable. For example, cannot be compared the turnover of an entity performing in poultry with the turnover of an entity that has as object of activity cutting of wood.

We propose the following steps to achieve a reliable Top of the Companies:

$>$ Classification of entities according to NACE codes ${ }^{(6)}$, regardless theirs' ownership and legal form. This classification is carried out on sections in accordance with Order 337/2007: section A - Agriculture, forestry and fishing, section B - Mining and quarrying, etc.

$>$ Gathering of indicators for every single company;

$>$ Testing the indicators to be considered for classification.

In table bellow we present the Top of the Companies form Alba County taking into consideration the following variables: turnover, net profit and total debt. 
Top of the Companies in Alba County proposed for 2009, based on turnover, net profit and total debt

\begin{tabular}{|c|l|r|r|r|}
\hline Position & \multicolumn{1}{|c|}{ Company name } & \multicolumn{1}{c|}{ Turnover } & \multicolumn{1}{c|}{ Net profit } & \multicolumn{1}{c|}{ Total debt } \\
\hline 1 & $\begin{array}{l}\text { SC HOLZINDUSTRIE } \\
\text { SCHWEIGHOFER SRL }\end{array}$ & $875.673 .942,00$ & $101.201 .282,00$ & $647.280 .701,00$ \\
\hline 2 & SC ELIT SRL & $304.892 .075,00$ & $35.582 .812,00$ & $84.650 .325,00$ \\
\hline 3 & SC TRANSAVIA SA & $304.178 .862,00$ & $14.363 .817,00$ & $108.665 .931,00$ \\
\hline 4 & SC ALBALACT SA & $225.975 .200,00$ & $2.603 .779,00$ & $95.603 .352,00$ \\
\hline 5 & SC MERCADO SRL & $152.485 .115,00$ & $3.731 .791,00$ & $31.561 .012,00$ \\
\hline 6 & SC PEHART TEC SA & $129.134 .483,00$ & $148.437,00$ & $176.213 .919,00$ \\
\hline 7 & SC JIDVEI SRL FILIALA ALBA & $89.198 .043,00$ & $3.470 .974,00$ & $48.771 .790,00$ \\
\hline 8 & SC REKORD SRL & $85.006 .137,00$ & $8.335 .294,00$ & $29.851 .498,00$ \\
\hline 9 & SC SUPREMIA GRUP SRL & $75.779 .641,00$ & $6.105 .029,00$ & $24.053 .840,00$ \\
\hline 10 & SC FLOREA GRUP SRL & $61.767 .444,00$ & $37.798,00$ & $35.154 .548,00$ \\
\hline 11 & SC POMPONIO SA & $59.034 .904,00$ & $634.245,00$ & $66.358 .724,00$ \\
\hline 12 & SC IPEC SA & $33.971 .135,00$ & $829.632,00$ & $9.884 .631,00$ \\
\hline 13 & SC ALOREF SRL & $22.803 .415,00$ & $398.626,00$ & $7.828 .693,00$ \\
\hline 14 & SC GRUP CORINT SA & $16.550 .766,00$ & $3.082 .197,00$ & $3.989 .961,00$ \\
\hline 15 & SC AUROCAR 2002 SRL & $10.567 .290,00$ & $274.886,00$ & $3.215 .932,00$ \\
\hline 16 & SC SIPATUB SA & $7.786 .408,00$ & $521.834,00$ & $1.744 .371,00$ \\
\hline 17 & SC BOSCH REXROTH SRL & $81.918 .700,00$ & $-1.550 .092,00$ & $167.176 .524,00$ \\
\hline 18 & SC KRONOSPAN SEBES SA & $547.973 .772,00$ & $-90.380 .485,00$ & $564.957 .727,00$ \\
\hline
\end{tabular}

For ease of calculation we make the following notations:

Value of turnover - X,

Value of debts - Y,

Average turnover - $\bar{X}$

Average debts $-\bar{Y}$

The ranking proposed in the above table was obtained by using the following arguments:

$>$ Entities in the first 10 positions were eliminated because they have registered losses in the profit and loss account. It is the case of SC KRONOSPAN SEBEŞ SA and SC BOSCH REXROTH SRL.

$>$ The place of the 2 companies previously eliminated was taken by SC SUPREMIA GRUP SRL and SC FLOREA GRUP SRL because they registered net profit at the end of fiscal year, in amount of 6.105.029,00 lei and respectively 37.798,00 lei.

$>$ After these corrections we will test in the table below the correlation between turnover and total debt in order to verify if the sales are correlated with the obligations of entities.

The proposed ranking could have taken into account also other indicators of performance analysis based on added value created. For example: economic value added, market value added, liquid value added (Vâlceanu et. al., 2005).

A part of these indicators could not be determined for entities in Alba County because only a small part of them are listed on the stock exchange. 
Table no. 8 .

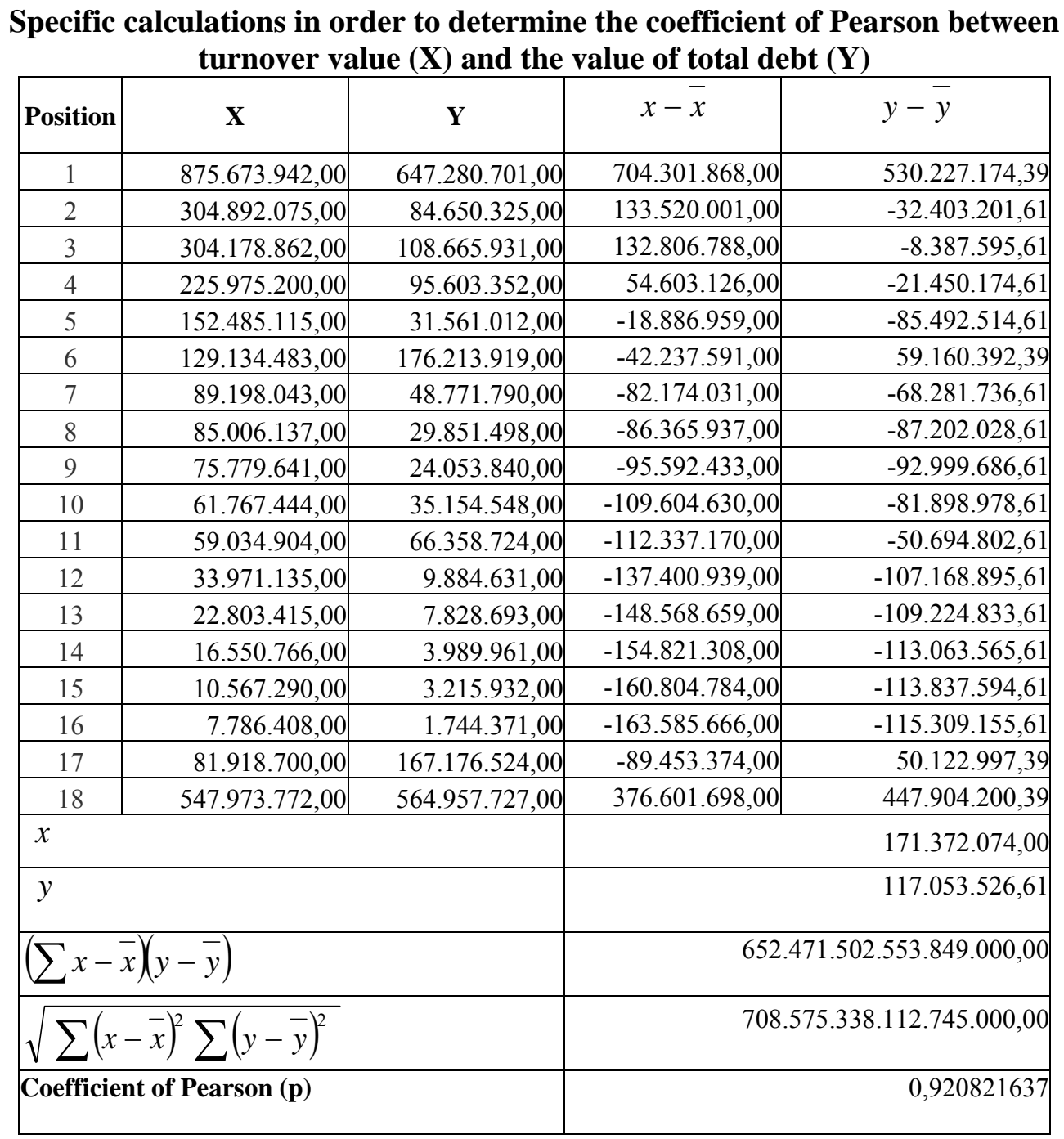

The Pearson product-moment correlation coefficient is a dimensionless index, a measure of the correlation (linear dependence) between two variables $\mathrm{X}$ and $\mathrm{Y}$, giving a value between +1 and -1 inclusive:

$$
-1<\mathrm{p}<+1 \quad 5
$$

Based on previously determined coefficients we can draw the following assertions:

Between turnover and the value of debt is a strong dependency relationship. This statistic aspect shows that goods bought, respectively finished goods obtained were used for firm's activity object and not for other purposes;

$>$ Can be estimated even economic policies applied by the entities in general.

The strong dependence relationship between turnover and total debt shows that the obligations of the entities are related to the object of activity and thus the ranking presented in Table 7 is properly elaborated. In this way there are no longer needed corrections over the top we propose. The corrections in the ranking were needed only if the Pearson's coefficient tended to zero. 


\section{Conclusions}

First conclusion: the Top of the Companies issued by Alba Chamber of Commerce, Industry and Agriculture taking into account only the turnover is not realistic, because the coefficient of variation is very high. In order this top to meet even its own rules of the Chamber of Commerce, Industry and Agriculture should have been taken into consideration for classification also other indicators, such as gross or net profit. The rankings includes entities, which despite having a high turnover, records gross loss, net loss, etc.

Second conclusion: a new Top of the Companies in Alba County was elaborated taking into account also other significant indicators together with turnover: net profit and total debt. By determining Pearson's coefficient was validated the raking we have proposed, whereas it was fund out a strong link between the amount of turnover and value of total debt at the 18 entities selected for classification.

Third conclusion: comparing the ranking elaborated by the Alba County Chamber of Commerce, Industry and Agriculture with the one proposed by us we found out that: SC KRONOSPAN SEBEŞ SA and SC BOSCH REXROTH SRL were eliminated from the ranking, as recorded at year-end loss, the top entered the following entities: SC SUPREMIA GRUP SRL for position 9 and SC FLOREA GRUP SRL to position 10.

We consider that the above mentioned conclusions address strictly to Chamber of Commerce and Industry of Romania in order to amend its own Regulation and to achieve the Top of the Companies based on several relevant indicators. This legal obligation of the Chamber of Commerce and Industry can be performed annually without distorting the reality and in order to provide correct and accurate information to the public. This Top of the Companies can be regarded in terms of publicity made for the entities, encouraging them to perform profitable economic activities that generate cash flows.

\section{Notes}

(1) The liquidator is obliged to examine the debtor's activity and to report on the causes and circumstances that led to the stop of debtor payments.

(2) In Romania, the financial year usually coincides with calendar year, i.e $1^{\text {st }}$ January to $31^{\text {th }}$ December N. This rule is imposed by the Romanian legislation for all entities, with certain exceptions.

${ }^{(3)}$ In Canada, the financial year is usually from $1^{\text {st }}$ October $N$ until la $30^{\text {th }}$ September $N+1$.

(4) The amounts are for the period $1^{\text {st }}$ October $\mathrm{N}-1-30^{\text {th }}$ November $\mathrm{N}$.

(5) The score was calculated by the Alba County Chamber of Commerce, Industry and Agriculture in relation to company with the highest turnover (which has score 100). For example SC TRANSAVIA SA obtained a score of $34.7 \%$. It was calculated by dividing the turnover of the SC TRANSAVIA SA for 2009 with the turnover of SC HOLZINDUSTRIE SCHWEIGHOFER SRL, respectively:

$$
\frac{304.178 .862 \text { lei }}{875.673 .942 \text { lei }} \times 100 \approx 34,70 \% \text { (see table } 4 \text { ). }
$$

(6) NACE (National Classification of Economic Activities) is the acronym used to designate the national statistical classification of economic activities in Romania. This classification was designed to allow grouping based on homogeneity criteria of data about "statistical units" such as, for example, a plant or group of plants constituting an economic entity, an enterprise (the Order of the President of National Institute of Statistics regarding the updating of national economy classification of activities - NACE no. 337/2007, Official Journal no. 293/2007). 


\section{References}

1. Feleagă N., Malciu L., Bunea Ş., 2002. Bazele Contabilităţii - o abordare europeană şi internațională. Bucharest, Publisher Economică.

2. Hsu C. C., Boggs D. J., 2003. Internationalization and Performance: Traditional Measures and Their Decomposition, Multinational Business Review, volume 11, issue 3, pp. 23 - 50.

3. Vâlceanu G., Robu V., Georgescu N., 2005. Analiză economico-financiară. Bucharest, Publisher Economică.

4. Order no. 3055/2009 for approval of accounting regulations in accordance with European Directives, Official Journal no. 766 bis/2009.

5. Order no. 509/2011 of the president of Authority for Regulating and Monitoring Public Procurement regarding qualification and selection criteria drawing up, Official Journal no. $687 / 2011$

6. Order of the President of National Institute of Statistics regarding the updating of national economy classification of activities - NACE no. 337/2007, Official Journal no. 293/2007.

7. http://www.mfinante.ro/agentinume.html?pagina=domenii, 3 December 2011.

8. http://www.cciaalba.ro/top_ca.html, 3 December 2011. 